\title{
Introducing the Physical Barriers in the City In-Between Buildings for Disabled Runners
}

\author{
Najmaldin Al-Taesh*, Katarzyna Ujma-Wasowicz ${ }^{*}$ \\ Faculty of Architecture, Silesian University of Technology, Gliwice, Poland \\ Email: ${ }^{\star N}$ ajmaldin.Hussein.Mohammed.Al-Taesh@polsl.pl
}

How to cite this paper: Al-Taesh, N., \& Ujma-Wasowicz, K. (2021). Introducing the Physical Barriers in the City In-Between Buildings for Disabled Runners. Current Urban Studies, 9, 554-573.

https://doi.org/10.4236/cus.2021.93033

Received: August 15, 2021

Accepted: September 7, 2021

Published: September 10, 2021

Copyright $\odot 2021$ by author(s) and Scientific Research Publishing Inc. This work is licensed under the Creative Commons Attribution International License (CC BY 4.0).

http://creativecommons.org/licenses/by/4.0/

\section{(c) (i) Open Access}

\begin{abstract}
Mass street running has become one of the most popular sports that has taken place in the city's center for many years. The interest in the participation of people with disabilities in street running has increased. Policymakers and urban planners are also aware that improperly designed public spaces create a physical barrier for disabled people to participating in street running independently. However, very limited research exists to introduce physical barriers in public spaces for disabled runners. The aim of this research was to introduce perceived physical barriers in the city in-between buildings for disabled runners. The data were randomly collected through an online survey of 110 disabled street runners. Chi-square analysis was carried out to find the results of perceived physical street elements and the avoidance of the running environment's surfaces that become barriers for disabled runners. The t-Test was conducted to explore differences between physically disabled and visually impaired runners in their perception of the barriers of the running environment. This study concluded the perceived types of street surfaces that should be avoided in running environments and perceived barriers in-between buildings that have a negative impact on the organization of running for disabled runners. However, the perceived attributes in-between buildings positively influence running organizations and encourage participation of physically disabled and visually impaired runners in the running environment. Urban practitioners should prioritize revitalizing in-between buildings through developing accessibility to remove all the impediments that may encourage and promote more disabled people to participate in street running.
\end{abstract}

\section{Keywords}

Mass Street Running, Disability Runners, Accessibility Design, In-Between Buildings, Physical Barriers, Revitalization 


\section{Introduction}

According to the World Health Organization (WHO), about 15 percent of people with different types of disabilities live in the world. They further point to the fact that this figure is growing and is expected to continue in the next several years, as well as having inferior outcomes in health [WHO, 2011b]. Many studies have shown that sufficient information exists for people with disabilities and non-disabled people who participate in sports and physical activities to improve their health [Lamprecht \& Stamm, 2006; Kerins, 2005; Edwards \& Tsouros, 2008; WHO, 2011a; Kostrzewska, 2017; Smith et al., 2018; Smith \& Sparkes, 2019], especially in running [Bodin \& Hartig, 2003; Vaandrager, 2007]. Over the past few decades, mass street running has become one of the most popular sports for everyone that has taken place in public spaces [Burfoot, 2007; Scheerder et al., 2015; Ettema, 2016; Deelen et al., 2019]. A growing interest in wheelchair racing among athletes with disabilities has emerged, which has become vital to identifying areas where more research is required [Cooper, 1990]. Nowadays, public spaces in cities are welcomed by organizing different events [Ujma-Wąsowicz, 2012; Smith, 2015], as well as by Carmona and Gehl asserting that public spaces should be accessible to everyone [Carmona, 2010; Gehl, 2010; Ujma-Wąsowicz et al., 2021]. Running in public places has grown in popularity, particularly on public roads [Cooper, 1990; Tiessen-Raaphorst, 2016; Deelen et al., 2019]. However, public spaces have been designed for someone who is healthy and strong [Xiang et al., 2006; Giles-Corti et al., 2019]. Moreover, Francis stated that existing physical barriers in public spaces create insufficient accessibility for people with disabilities, making it difficult for them to move around in the built environment [Francis, 2018], preventing them from participating in sports, physical activity, and social activities daily [Sholihah, 2001; DePauw \& Gavron, 2005; Scelza et al., 2005; Allender et al., 2006; Howie et al., 2012; Shields et al., 2012; Yiing et al., 2013; Hargie et al., 2015; Matthews et al., 2015; Wadey \& Day, 2018; Richardson et al., 2017; Diaz et al., 2019]. Studies have revealed that the built environment is necessary to integrate design for people with disabilities, leading them to participate in activities of social life [Belir \& Onder, 2013; Salha et al., 2020; Badawy et al., 2020]. Regarding those issues, this study focuses on the physical attributes on the built environment that become a hinderance to disabled people in running environment.

To improve the quality of life for disabled people in the United States, the Americans with Disabilities Act has developed the removal of physical barriers in the built environment through accessible and inclusive design [Ujma-Wąsowicz, 2011; Hums et al., 2016], which positively affects disabled people's ability to live independently and participate fully in all aspects of life [United NationsCRPD, 2006], and can promote the participation of people with disabilities in sports and physical activity as well as increase the number of opportunities for outdoor sports [Fields in Trust-London, 2008; Ujma-Wąsowicz \& Musioł, 2008; Swain et al., 2013; Mahmoudi \& Mazloomi, 2014; Bundon \& Hurd Clarke, 2015; 
Kostrzewska, 2017; Kiuppis, 2018; DESA, 2019; Szaszák \& Kecskés, 2020; Huang et al., 2020]. In this regard, a study published in Building for Equality for Disability in the Built Environment focused on aspects of inclusive streetscapes that require the removal of features [Women and Equalities Committee, 2018] and bad-condition surfaces [Toole et al., 1999]. In urban public spaces, various pavement surface materials, such as cobblestone, concrete, asphalt, blocks, and bricks, have been used and the decision about them depends on the functional requirements [Beuving \& Michaut, 2005]. The surfaces that cause barriers reduce the movement of people with disabilities, especially on wet roads for wheelchair street runners [Gleeson, 2001; Martin, 2002; Bromley, et al., 2007]. Jonas asserted that running on the surface forces the runner's body to [Jared, 2018]. In order to avoid causing a trip hazard and easily moving in public spaces, in particular for visually impaired people, the Department of the Environment, Transport and the Regions (DETR) concluded that connected streets and the material used for the surface should be level with the surrounding footpath and have good position of street amenities as well as having good quality conditions [DETR, 1998; Rimmer, 2006; Sport England, 2010; Kesik et al., 2012; Martin, 2013; Borgers, et al., 2016]. According to Peters, who studied transport in Japan to create a barrier-free environment, including no-step, curb cuts, and slopes in Japanese cities, for wheelchair users and visually impaired people [Peters, 2001; Stevens, 2007]. Moreover, several studies observed poorly designed and poor-quality paving materials are obstructions for people with disabilities [Meyers et al., 2002; Rimmer et al., 2005; Kirchner et al., 2008; Martin, 2013; Mohammed, 2016]. In this study, we concentrate on the physical attributes of the running environment that become the barriers for disabled runners in street running. Those environmental factors are positively related to sports participation, including access to sports facilities, street connectivity, and street design can be more usable for people with disabilities, but it may be difficult with decayed pavement materials and the poor condition of the streets [Kamphuis et al., 2008; Hoekman et al., 2017; Deelen et al., 2017; Hussein, 2018; Ismael et al., 2019]. Concerning the physical environment and various surfaces, Allen Collinson observed that smooth paving can be a more attractive environment for running. However, slopes, holes, muddy paths, and uneven pavements may make a difficult and less attractive environment for running and the chance of harm and injury may increase. Furthermore, the risk of injury and harm to runners is increased by poor street lighting and different types of transport, particularly cars. However, the quality of the running environment needs to be improved to avoid injuries to runners [Hockey \& Allen-Collinson, 2006; Collinson, 2008; Bashiti \& Rahim, 2016].

It is important that barriers and objects should be avoided in public spaces, leading to them being accessible with provisions for independent movement for all people [Shahraki, 2021]. The studies also found that cars, cyclists, and poor lighting on running streets are the most frequently experienced barriers in the built environment by able-body street runners. However, without cars, the run- 
ning frequency on paved streets has increased [Ettema, 2016; Deelen et al., 2019]. The objective of municipalities is to design cities by changing and improving the built environment to increase the attractiveness of urban running environments in order to motivate people to keep running and to become more physically active [Breuer et al., 2011; Borgers et al., 2016; Gadais et al., 2018]. Regarding that, Clematis Street in America implemented the process of revitalization to achieve universally accessible streets that are adaptable for special events [Robert, 2020]. It may promote of running environments for all [Titze et al., 2005].

Policymakers and urban planners are increasingly recognizing that public spaces may play an essential role in promoting active living for people with disabilities. Many studies have revealed evidence for the importance of objective physical environmental features on sports participation and physical activity, Fewer studies have been conducted to investigate how physical environmental attributes impact on disabled runners in the running environment as impediments [Cooper, 1990; Priyono et al., 2017]. Physical barriers are currently present in most urban public spaces, making it difficult for disabled street runners to independently participate in mass street running, despite an increased interest in disabled runners participating in running. However, very limited research exists about what particular physical attributes in public spaces make a barrier for physically and visually disabled street runners in the running environment, to address this research gap. The aim of this research was to introduce perceived physical barriers in the city in-between buildings for disabled runners.

\section{Materials and Methods}

\subsection{Participants and Study Design}

Data were collected from 150 disabled runners in May 2021, by using an online survey platform (Pollfish ${ }^{\circledR}$ tools). This cross-sectional study involved and considered only those men with disabilities who participated in street running and marathons in 2019, including the Shanghai Marathon, London Marathon, and Boston Marathon. They received the survey questions with a web link via email and social media, providing information about the purpose of the study and assurance that the data is anonymously processed according to the ethical principles of the declaration of Helsinki and used for research purposes only. The purpose of this study was to introduce perceived physical barriers in the city inbetween buildings for disabled runners and asked the participants to indicate and rate the physical barriers in the running environment. It was not necessary to complete all the questions and, finally, the questionnaire was completed in full by 110 disabled runners, including $56.36 \%$ of the respondents were physically disabled runners and $43.64 \%$ were visually impaired runners.

\subsection{Measures and Questionnaire}

For the particular aim of this research, the online questionnaire included 13 questions characterizing socio-demographics, the impotence of street surfaces and 
avoided surfaces, street elements that positively and negatively influence the organization of running and rated physical street elements that become barriers for disabled runners in the running environment. Analyzing socio-demographics included gender, age, country, and education control in this study. The following issues are related to these questions:

The first question was about the type of street surface important for a runner. That was measured with three items included (yes, no, and unsure). The second question asked the respondents to select which surface should be avoided and it was measured with five items included (uneven, various heights, cobblestones, concrete, and asphalt surfaces). The third question asked respondents to identify one of seven permanent street elements that positively influence the organization of the running environment (lighting, ramps, trees and green areas, flat surfaces, special lines, interesting architecture, and street connectivity). Furthermore, the negative impact on the organization of the running environment was measured using six items (curbs, street signs, lighting, various high streets, street turn, and elements (bins, benches, phone boxes, hydrants, bollards, manholes, and so on).The fourth question asked respondents to rate the perception of physical street elements that become barriers for physically disabled and visually impaired runners in street running (curbs, cars, cyclists, street signs, trees and green areas, benches, lighting, and trash receptacles) on a 5-point Likert-type scale ranging from one strongly disagree to five strongly agree.

- Is the type of surface on the street important for a runner?
$\square$ Yes
$\square$ No
$\square$ Unsure

- What surface should be avoided in the running environment?
Uneven
Various heights
Cobblestones
Concrete
$\square$ Asphalt

- Indicate specific, permanent street elements that positively influence the organization of the running environment for disabled runners.
lighting
Ramps
Tress \& green areas
$\square$ Flat surfaces
$\square$ Special lines
Interesting architecture
Street connectivity

- Indicate specific, permanent street elements that negatively influence the organization of the running environment for disabled runners.
Curbs
Street signs
$\square$ lighting
Various high surfaces
Street turn
elements

- How would you rate the following terms as barriers for disabled runners in the running environment?

\begin{tabular}{cccccc}
\hline Variables & $\begin{array}{c}\text { Strongly } \\
\text { disagree }\end{array}$ & Disagree & $\begin{array}{c}\text { Neither agree } \\
\text { nor disagree }\end{array}$ & Agree & $\begin{array}{c}\text { Strongly } \\
\text { disagree }\end{array}$ \\
\hline Curbs & $\square$ & $\square$ & $\square$ & $\square$ & $\square$ \\
Cyclists & $\square$ & $\square$ & $\square$ & $\square$ & $\square$ \\
Cars & $\square$ & $\square$ & $\square$ & $\square$ & $\square$ \\
\hline
\end{tabular}




\section{Continued}

\begin{tabular}{cccccc}
\hline Street signs & $\square$ & $\square$ & $\square$ & $\square$ & $\square$ \\
Benches & $\square$ & $\square$ & $\square$ & $\square$ & $\square$ \\
lighting & $\square$ & $\square$ & $\square$ & $\square$ & $\square$ \\
Tress \& green areas & $\square$ & $\square$ & $\square$ & $\square$ & $\square$ \\
Trash receptacles & $\square$ & $\square$ & $\square$ & $\square$ & $\square$ \\
\hline
\end{tabular}

\subsection{Data Analyses}

IBM SPSS Statistics 26.0 was used to analyze the data. Analyses using chi-square were performed to test the differences between physically disabled and visually impaired runners' perception of the importance of running on environmental surfaces. Respondents' perception of the permanent street elements that positively and negatively influence the organization of running and avoidance of the running environment's surfaces was analyzed using frequency statistics. A one-sample t-test was conducted to explore differences between physically disabled runners and visually impaired runners in the perception of the barriers (curbs, cyclists, cars, street signs, benches, lighting, trees and green areas, and trash receptacles) of the running environment. An alpha level of.05 was used.

\section{Results}

\subsection{Descriptive Results and Differences between Physically and Visually Disabled Runners}

Of the total respondents, $56.36 \%$ were physical disability runners and $43.64 \%$ were visually impaired runners (Table 1). Most respondents were between 25 34 years old (30.65\% of physical disability and $45.83 \%$ of visually impaired runners) and the minority of them were between $16-17$ and $>54$ years old.

$18.72 \%$ had a lower or middle level of education compared to a higher $81.26 \%$. Respondents were from a variety of continents, including Europe $+\mathrm{GB}$, North and South America, Africa, and Asia.

$89.09 \%$ of disability runners agree that the type of street surface is important for runners. Uneven and potholed surfaces were chosen by $32.72 \%$ of the runners, and various high surfaces were chosen by $29.99 \%$ of the runners. Lighting and flat surfaces (20.0\% and $10.0 \%$, respectively) were positive, but curbs, street signs, and various high surfaces $(17.27 \%, 7.27 \%$, and $8.18 \%$, respectively) had a negative impact on the organization of the run for visually impaired runners.

Lighting, flat surfaces, and interesting architecture (15.45\%, 17.27\%, and 7.27\%, respectively) were positive, but curbs, elements (bins, hydrants, bollards, phone boxes, etc.), and various high surfaces (14.54\%, 9.09\%, and $17.27 \%$, respectively) had a negative impact on the organization of the run for physical disability runners.

In the running environment, the average of curbs, street signs, and cars is perceived to be a greater barrier than cyclists, lighting, trees and green areas, and 
Table 1. Descriptive statistics of respondents with physical disabilities and visually impaired runners.

\begin{tabular}{|c|c|c|c|}
\hline Variables & $\begin{array}{l}\text { Physical disabled runners } \\
\qquad(\mathrm{N}=62 ; 56.36 \%)\end{array}$ & $\begin{array}{l}\text { Visually impaired runners } \\
\quad(\mathrm{N}=48 ; 43.64 \%)\end{array}$ & $\begin{array}{c}\text { Total } \\
(\mathrm{N}=110) \%\end{array}$ \\
\hline \multicolumn{4}{|l|}{ Age (\%) } \\
\hline $16-17$ year & 4.84 & 0.00 & 2.73 \\
\hline $18-24$ year & 16.13 & 25.00 & 20.00 \\
\hline 25 - 34 year & 30.65 & 45.83 & 37.27 \\
\hline 35 - 44 year & 27.42 & 22.92 & 25.45 \\
\hline 45 - 54 year & 17.74 & 2.08 & 10.91 \\
\hline$>54$ year & 3.23 & 4.17 & 3.64 \\
\hline Male (\%) & 56.36 & 43.64 & 100.00 \\
\hline \multicolumn{4}{|l|}{ Education (\%) } \\
\hline Lower or middle & 22.58 & 14.90 & 18.72 \\
\hline Higher & 77.42 & 85.10 & 81.26 \\
\hline \multicolumn{4}{|l|}{ Continent (\%) } \\
\hline Europe + GB & 9.09 & 8.18 & 17.27 \\
\hline North America & 31.81 & 14.54 & 46.36 \\
\hline South America & 2.72 & 4.54 & 7.27 \\
\hline Africa & 3.63 & 2.72 & 6.36 \\
\hline Asia & 9.09 & 13.63 & 22.72 \\
\hline \multicolumn{4}{|c|}{ Is the type of surface on the street important for a runner? (\%) } \\
\hline Yes & 50.00 & 39.09 & 89.09 \\
\hline No & 3.36 & 2.72 & 6.36 \\
\hline Unsure & 2.72 & 1.81 & 4.55 \\
\hline \multicolumn{4}{|c|}{ What surface should be avoided? (\%) } \\
\hline Various high surfaces & 13.63 & 16.36 & 29.99 \\
\hline Uneven & 20.00 & 12.72 & 32.72 \\
\hline Cobblestones & 11.81 & 6.36 & 18.17 \\
\hline Concrete & 7.27 & 5.45 & 12.72 \\
\hline Asphalt & 3.63 & 2.72 & 6.36 \\
\hline \multicolumn{4}{|c|}{ Positively influence the organization of the running environment (\%) } \\
\hline Lighting & 15.45 & 20.00 & 35.45 \\
\hline Ramps & 5.45 & 0.90 & 6.35 \\
\hline Tress and green area & 4.54 & 0.90 & 5.44 \\
\hline Flat and smooth surface & 17.27 & 10.00 & 27.27 \\
\hline Special line & 0.90 & 3.63 & 4.26 \\
\hline Interesting architecture & 7.27 & 0.90 & 8.17 \\
\hline Sidewalk connectivity & 4.54 & 5.45 & 9.99 \\
\hline \multicolumn{4}{|c|}{ Negatively influence the organization of the running environment (\%) } \\
\hline Curbs & 14.54 & 17.27 & 31.81 \\
\hline Street signs & 8.18 & 7.27 & 15.45 \\
\hline Lighting & 2.72 & 0.90 & 3.62 \\
\hline Various high surface & 17.27 & 8.18 & 25.45 \\
\hline Street turn (curve) & 2.72 & 0.90 & 3.62 \\
\hline Other elements & 9.09 & 7.27 & 16.36 \\
\hline \multicolumn{4}{|l|}{ Physical barriers, mean } \\
\hline Curbs & 3.39 & 3.44 & 6.83 \\
\hline Cyclists & 3.24 & 3.13 & 6.37 \\
\hline Cars & 3.18 & 3.50 & 6.68 \\
\hline Signages (street signs) & 3.27 & 3.44 & 6.71 \\
\hline Benches & 3.13 & 2.98 & 6.11 \\
\hline Lighting & 3.34 & 3.06 & 6.40 \\
\hline Trees and green area & 3.34 & 3.17 & 6.51 \\
\hline Bins & 3.05 & 2.96 & 6.01 \\
\hline
\end{tabular}


bins for both physically disabled and visually impaired runners. Finally, runners more frequently perceive that the features of the running environment, such as high surfaces, uneven surfaces, curbs, and cars, create barriers for both physically and visually disabled runners from participating in street running.

\subsection{Respondents' Perception of Important and Avoided Surfaces of the Running Environment for Disabled Runners}

Table 2 shows the results of an analysis of frequency data on the perceived importance of the running environment's surface, which was chosen at random from a group of 110 runners with disabilities (62 physically disabled runners and 48 visually impaired runners). One of the survey statements was their perception of what kind of street surface is important for a runner. $89.09 \%$ of the runners said yes, $6.36 \%$ said no, and $4.55 \%$ had no idea what was important on the street's surface.

Table 3 provides that there was no significant relationship between disabled runners and the importance of the running environment surfaces, $\chi^{2}(108)=$ $0.031, p>0.985$. The reason for this was those runners with physical disabilities and those who are visually impaired could agree on the importance of the running surface.

Respondents were asked to indicate what surfaces should be avoided in the running environment (Figure 1). The indicated surfaces that should be avoided for both disabled runners were uneven and various high surfaces were more recorded than concrete and asphalt surfaces. Physically disabled runners were highly recorded for uneven surfaces at $20.0 \%$ and various high surfaces at $13.63 \%$, compared to concrete at $7.27 \%$ and asphalt surfaces at $3.63 \%$. Visually impaired runners were rated higher for various high surfaces at $16.36 \%$ and uneven surfaces at $12.72 \%$, compared to concrete at $5.45 \%$ and asphalt surfaces at $2.72 \%$. In addition, cobblestone surfaces at $11.81 \%$ and $6.36 \%$ for both physically disabled and visually impaired runners, respectively.

Table 2. Analysis of the frequency of the perceived importance of the running environment surface.

\begin{tabular}{|c|c|c|c|c|c|}
\hline & \multicolumn{2}{|c|}{$\begin{array}{l}\text { Physical disabled runners } \\
\qquad(\mathrm{N}=62 ; 56.36 \%)\end{array}$} & \multicolumn{2}{|c|}{$\begin{array}{l}\text { Visually impaired runners } \\
\qquad(\mathrm{N}=48 ; 43.64 \%)\end{array}$} & \multirow{2}{*}{$\begin{array}{c}\text { Total } \\
(\mathrm{N}=110) \\
\%\end{array}$} \\
\hline & Frequency & Percent & Frequency & Percent & \\
\hline Yes & 55 & 50.00 & 43 & 39.09 & 89.09 \\
\hline No & 4 & 3.36 & 3 & 2.72 & 6.36 \\
\hline Unsure & 3 & 2.72 & 2 & 1.81 & 4.55 \\
\hline
\end{tabular}

Table 3. Chi-square test of independence on perceived importance of the running environment surfaces.

\begin{tabular}{cccc}
\hline Total $(\mathrm{N}=110)$ & $\chi^{2}$ & $\mathrm{df}$ & $p$-value \\
\hline 110 & $0.031^{\mathrm{a}}$ & 2 & 0.985 \\
\hline
\end{tabular}




\subsection{Respondents' perception of the permanent street elements that positively and negatively influence the organization of running for disabled runners}

Respondents were asked to rate the permanent street elements that positively influence the organization of running for disabled runners, including lighting, ramps, trees and green areas, flat surfaces, special lines, interesting architecture, and sidewalk connectivity (Figure 2). Physically disabled runners were frequently rated at $17.27 \%, 15.45 \%, 7.27 \%, 5.45 \%, 4.54 \%, 4.54 \%$, and $0.9 \%$ for flat surfaces,

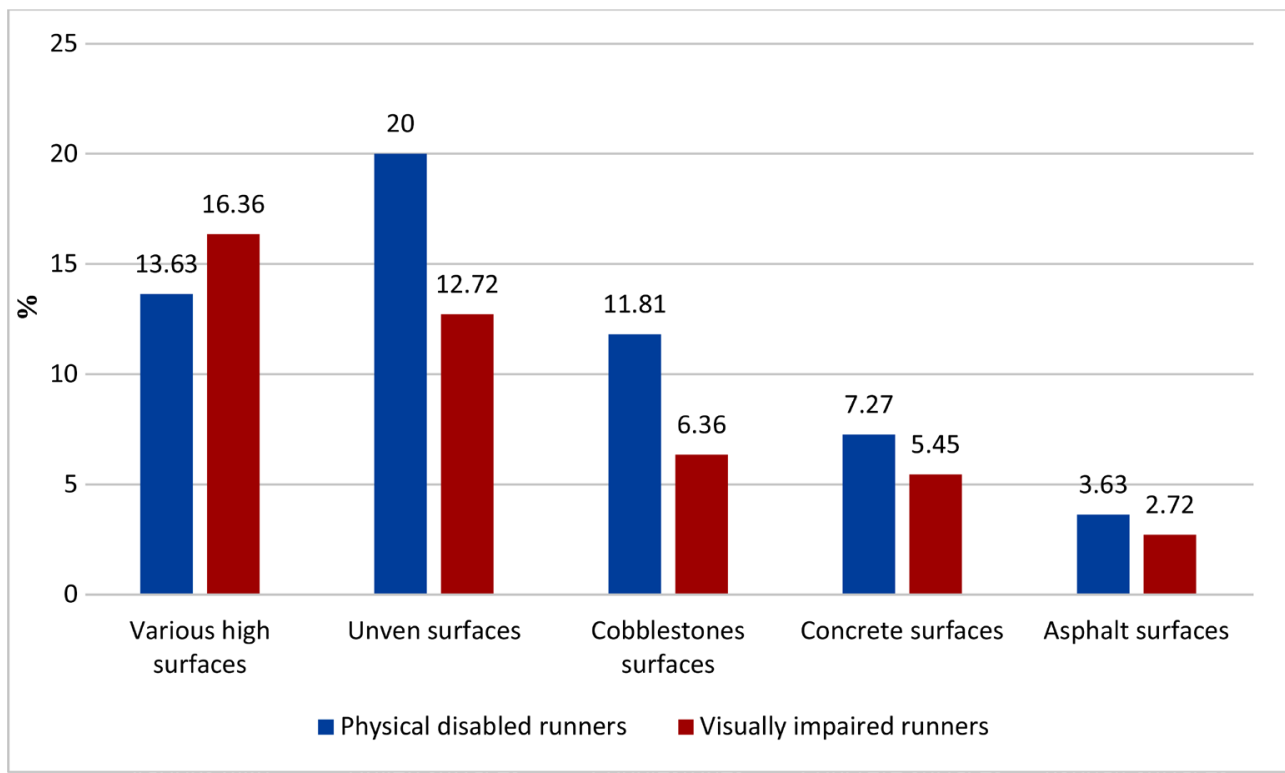

Figure 1. Distribution of respondents avoiding running surfaces for physically disabled and visually impaired runners.

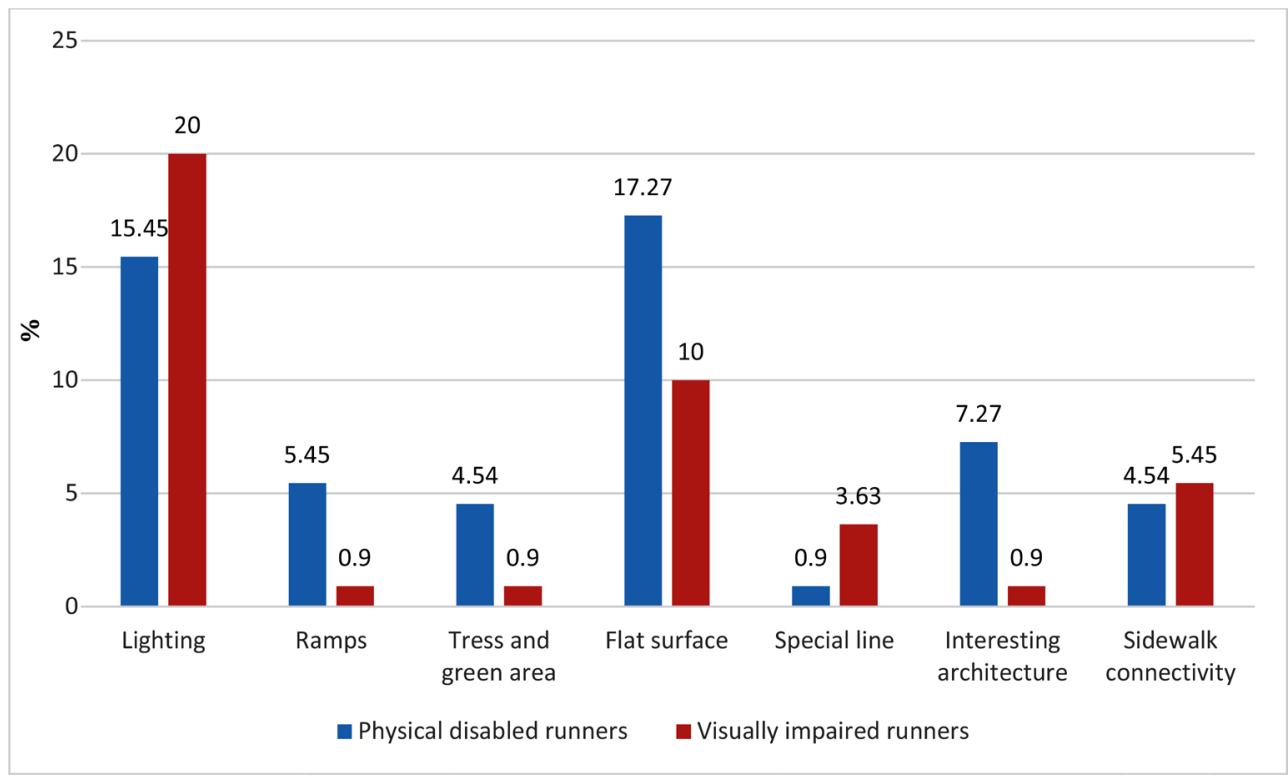

Figure 2. Distribution of respondents of the permanent street elements that positively influence the organization of running by physical disabled and visually impaired runners. 
lighting, interesting architecture, ramps, sidewalk connectivity, trees and green areas, and special lines, respectively. Visually impaired runners were frequently scored at $20.0 \%, 10.0 \%, 5.45 \%, 3.65 \%, 0.90 \%, 0.90 \%$, and $0.9 \%$ for lighting, flat surfaces, sidewalk connectivity, special lines, ramps, interesting architecture, and trees and green areas, respectively.

Respondents were asked to rate the permanent street elements that negatively influence the organization of running for disabled runners, including curbs, street signs, lighting, and various high surfaces, street turns, and elements (bins, benches, phone boxes, hydrants, bollards, manholes, etc.) (Figure 3). Physical disabled runners were frequently scored at $17.27 \%, 14.54 \%, 9.09 \%, 8.18 \%, 2.27 \%$, and $2.27 \%$ for various high surfaces, curbs, elements, street signs, lighting, and street turns, respectively. Visually impaired runners were frequently scored at $17.24 \%$, $8.18 \%, 7.27 \%, 7.27 \%, 0.90 \%$, and $0.90 \%$ for curbs, various high surfaces, street signs, elements, lighting, and street turns, respectively.

\subsection{Respondents' Perception of the Barriers in the Running Environment}

Table 4 provides descriptive statistics for both disabled runners. Regarding the questions for both types of disabled runners, rate the characteristics of the built environment that become the barriers to participation in street running. Physically disabled runners recorded significantly higher results for curbs, inappropriate position of lighting, street signs, and trees and green areas $(\mathrm{M}=3.3 ; \mathrm{SD}=$ $1.17, \mathrm{M}=3.3 ; \mathrm{SD}=1.24, \mathrm{M}=3.2 ; \mathrm{SD}=1.14$, and $\mathrm{M}=3.3 ; \mathrm{SD}=1.31$, respectively) as barriers in the running environment compared to cyclists, cars, benches, and trash receptacles $(\mathrm{M}=3.2 ; \mathrm{SD}=1.12, \mathrm{M}=3.1 ; \mathrm{SD}=1.33, \mathrm{M}=3.1 ; \mathrm{SD}=$

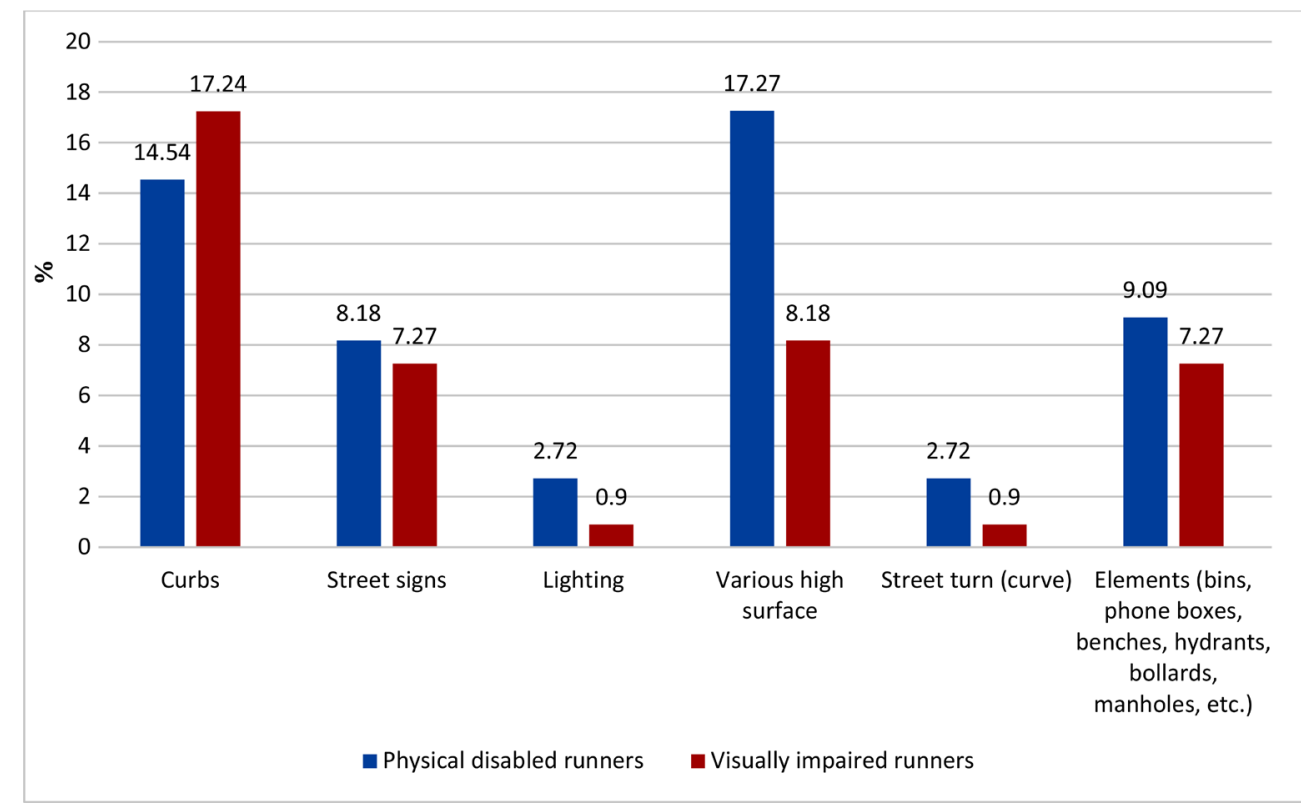

Figure 3. Distribution of respondents of the permanent street elements that negatively influence the organization of running by physical disabled and visually impaired runners. 
1.23 , and $\mathrm{M}=3 ; \mathrm{SD}=1.20$, respectively). Visually disabled runners recorded significantly higher results for cars, curbs, and street signs $(\mathrm{M}=3.5 ; \mathrm{SD}=1.23$, $\mathrm{M}=3.4 ; \mathrm{SD}=1$, and $\mathrm{M}=3.2 ; \mathrm{SD}=1.14$, respectively) as barriers in the running environment compared to cyclists, benches, lighting, trees and green areas, and trash receptacles $(\mathrm{M}=3.1 ; \mathrm{SD}=1.24, \mathrm{M}=2.9 ; \mathrm{SD}=1.21, \mathrm{M}=3 ; \mathrm{SD}=1.27, \mathrm{M}=$ 3.1; $\mathrm{SD}=1.35$, and $\mathrm{M}=2.9 ; \mathrm{SD}=1.14$, respectively). Conclusively, visually disabled runners more strongly suggest that cars as a barrier as well as both disabled runners more frequently perceive curbs as a barrier to the running environment.

Table 5 shows the results of analyses of a t-test sample on respondents' perceptions of barriers in the running environment for both disabled runners. Physical disabled runners scored the barriers highly in the running environment for curbs, lighting, and trees and green areas $(\mathrm{t}(61)=2.587, p<0.05, \mathrm{t}(61)=2.150$, $p<0.05$, and $\mathrm{t}(61)=2.024, p<0.05$, respectively) than cyclists, cars, street signs, benches, and trash receptacles $(\mathrm{t}(61)=1.691, p>0.05, \mathrm{t}(61)=1.045, p>0.05, \mathrm{t}$ $(61)=1.881, p>0.05, \mathrm{t}(61)=0.823, p>0.05$, and $\mathrm{t}(61)=0.316, p>0.05$, respectively). Visually impaired runners scored the barriers highly in the running environment for curbs, cars, and street signs $(\mathrm{t}(47)=2.887, p<0.05, \mathrm{t}(47)=$ $2.799, p<0.05$, and $\mathrm{t}(47)=2.561, p<0.05$, respectively) than cyclists, benches, lighting, trees and green areas, and trash receptacles $(\mathrm{t}(47)=0.694, p>0.05$,

Table 4. Descriptive statistics of respondents' perception of the barriers of the running environment by physical and visually disabled runners.

\begin{tabular}{ccccc}
\hline Variables & $\begin{array}{c}\text { Physical and visually } \\
\text { disabled runners }\end{array}$ & Mean & $\begin{array}{c}\text { Std. } \\
\text { Deviation }\end{array}$ & $\begin{array}{c}\text { Std. Error } \\
\text { Mean }\end{array}$ \\
\hline Physical disabled runners & $(\mathrm{N}=62 ; 56.36 \%)$ & & & \\
Curbs & 62 & 3.39 & 1.178 & 0.150 \\
Cyclists & 62 & 3.24 & 1.126 & 0.143 \\
Cars & 62 & 3.18 & 1.337 & 0.170 \\
Street signs & 62 & 3.27 & 1.148 & 0.146 \\
Benches & 62 & 3.13 & 1.235 & 0.157 \\
Lighting & 62 & 3.34 & 1.241 & 0.158 \\
Tress \& green area & 62 & 3.34 & 1.318 & 0.167 \\
Trash receptacles & 62 & 3.05 & 1.207 & 0.153 \\
Visually disabled runners & $(\mathrm{N}=48 ; 43.64 \%)$ & & & \\
Curbs & 48 & 3.44 & 1.050 & 0.152 \\
Cyclists & 48 & 3.13 & 1.248 & 0.180 \\
Cars & 48 & 3.50 & 1.238 & 0.179 \\
Street signs & 48 & 3.44 & 1.183 & 0.171 \\
Benches & 48 & 2.96 & 1.211 & 0.175 \\
Lighting & 48 & 3.06 & 1.278 & 0.185 \\
Tress \& green area & 48 & 3.17 & 1.358 & 0.196 \\
Trash receptacles & 48 & 2.96 & 1.148 & 0.166 \\
\hline
\end{tabular}


Table 5. $\mathrm{t}$-Test on perceived barriers of the running environment by physical and visually disabled runners.

\begin{tabular}{|c|c|c|c|c|c|c|}
\hline \multirow{2}{*}{ Variables } & \multirow{2}{*}{$\mathrm{t}$} & \multirow{2}{*}{$\mathrm{df}$} & \multirow{2}{*}{$\begin{array}{c}\text { Sig. } \\
\text { (2-tailed) }\end{array}$} & \multirow{2}{*}{$\begin{array}{c}\text { Mean } \\
\text { Difference }\end{array}$} & \multicolumn{2}{|c|}{$95 \% \mathrm{CI}$} \\
\hline & & & & & Lower & Upper \\
\hline \multicolumn{7}{|c|}{ Physical disabled runners } \\
\hline Curbs & 2.587 & 61 & 0.012 & 0.387 & 0.09 & 0.69 \\
\hline Cyclists & 1.691 & 61 & 0.096 & 0.242 & -0.04 & 0.53 \\
\hline Cars & 1.045 & 61 & 0.300 & 0.177 & -0.16 & 0.52 \\
\hline Street signs & 1.881 & 61 & 0.065 & 0.274 & -0.02 & 0.57 \\
\hline Benches & 0.823 & 61 & 0.414 & 0.129 & -0.18 & 0.44 \\
\hline Lighting & 2.150 & 61 & 0.036 & 0.339 & 0.02 & 0.65 \\
\hline Tress \& green area & 2.024 & 61 & 0.047 & 0.339 & 0.00 & 067 \\
\hline Trash receptacles & 0.316 & 61 & 0.753 & 0.048 & -0.26 & 035 \\
\hline \multicolumn{6}{|c|}{ Visually disabled runners } & 0.35 \\
\hline Curbs & 2.887 & 47 & 0.006 & 0.438 & 0.13 & 0.74 \\
\hline Cyclists & 0.694 & 47 & 0.491 & 0.125 & -0.24 & 0.49 \\
\hline Cars & 2.799 & 47 & 0.007 & 0.500 & 0.14 & 0.86 \\
\hline Street signs & 2.561 & 47 & 0.014 & 0.438 & 0.09 & 0.78 \\
\hline Benches & -0.119 & 47 & 0.906 & -0.021 & -0.37 & 0.33 \\
\hline Lighting & 0.339 & 47 & 0.736 & 0.063 & -0.31 & 0.43 \\
\hline Tress \& green area & 0.850 & 47 & 0.399 & 0.167 & -0.23 & 0.56 \\
\hline Trash receptacles & -0.252 & 47 & 0.803 & -0.042 & -0.37 & 0.29 \\
\hline
\end{tabular}

$\mathrm{t}(47)=-0.119, p>0.05, \mathrm{t}(47)=0.339, p>0.05, \mathrm{t}(47)=0.850, p>0.05$, and $\mathrm{t}$ $(47)=-0.252, p>0.05$, respectively).

Both disabled runners stated that the curbs had become a hindrance to their running environment. Additionally, physical disabled runners have indicated that lighting and trees and green areas, while visually impaired runners have reported significant differences as cars and street signs become a barrier to their running environment. However, they scored less important results on the perception of barriers for cyclists, benches, and trash receptacles in the running environment.

\section{Discussion}

This study examined perceived street surfaces and permanent street features that become impediments for physically disabled and visually impaired runners in mass street running in urban public spaces. The main finding of this study was that the perception of the importance of street surfaces and the physical attributes of streets in-between buildings has become a barrier that positively and negatively influences the organized running environment for disabled runners.

Physically disabled and visually impaired runners also agree about the importance of different types of running surfaces for runners. They indicated more frequently the surfaces to avoid in the running environment were uneven surfaces, various high surfaces, and cobblestone surfaces that have a negative rela- 
tionship between them and the participation of disabled runners in street running. Furthermore, the risk of injury and harm to runners has increased [Collinson, 2008]. However, they are less visible in the running environment on the surfaces of concrete and asphalt. Jonas also asserted that running on the surface forces the runner's body to work and further concluded that asphalt is the best when compared with concrete and grass [Jared, 2018].

Physically disabled runners more frequently indicate the importance of permanent street elements that positively influence the organization of running in-between buildings, including flat surfaces, lighting, and interesting architecture. In addition, Robert Steutevile asserted that flat surfaces and attractive architectural features enable them to be adaptable for special events [Robert, 2020] and promote a running environment for all [Titze et al., 2005]. However, ramps, sidewalk and street connectivity, trees and green areas, and special lines were less concerned about positively influencing the organization of the race.

Visually impaired runners more frequently indicate the importance of lighting, flat surfaces, sidewalk connectivity, and special lines (tactile pavers) in the running environment that positively influence the organization of running in-between buildings. However, ramps, trees, and green areas were less concerned with positively influencing the running organization. The study noted that trees (fallen branches) and ramps are a barrier for visually impaired people in the built environment [Rimmer, 2006; Martin, 2013].

Physically disabled and visually impaired runners more frequently indicate the importance of permanent street elements that negatively influence the organization of running in-between buildings, including various high surfaces, curbs, elements, street signs, and lighting. The study also revealed that inappropriate placement of street furniture [Sport England, 2010], poor lighting on running streets [Ettema, 2016; Deelen et al., 2019] have become barriers for street runners in running environments. Furthermore, Curbs, cyclists, cars, street signs, benches, lighting, trees and green areas, and trash receptacles are examples of perceived physical barriers in the running environment that have a negative impact on organizing street running for both physically disabled and visually impaired runners. As well as Curbs, lighting, and trees and green areas are perceived as barriers in the running environment by physically disabled runners, rather than cyclists, cars, street signs, benches, and trash receptacles. Visually impaired runners place a high value on barriers in the running environment, such as curbs, cars, and street signs, rather than cyclists, benches, lighting, trees, and green spaces.

Those physical barriers were found in this study that make it difficult to move in public spaces independently for all disabled runners. However, very few differences in perceived physical barriers between physically disabled runners and visually impaired runners in-between buildings were found. Furthermore, this study found that curbs, lighting, and trees and green areas were perceived as more of a barrier to physically disabled runners in the running environment. 
The findings of this study reveal that improperly designing public spaces makes it difficult and prevents disabled runners from participating in street running independently. However, the interest in the participation of disabled runners in mass street running has increased. It is obvious that urban planners and policymakers need to give more priority to revitalizing public spaces for people with disabilities by developing accessibility to remove all the barriers in the physical environment that can be adapted for organizing various events, especially mass street running. It also participates in improving the quality of life of people with disabilities in urban public spaces. Further study can be conducted to investigate what physical attributes in the built environment can create attractive public spaces for disabled runners in order to increase and motivate participation in street running as well as women's disabled runners can be taken into account for street running participation.

\section{Conclusion}

Over the past few decades, mass street running has become one of the most popular sports for everyone that has taken place in public spaces. People with disabilities are becoming increasingly interested in participating in street running. Policymakers and urban planners are also aware that improperly designed public spaces become physical barriers for disabled runners to participating in street running independently.

This research found that perceived types of street surfaces should be avoided in running environments for both physically disabled and visually impaired runners, such as uneven and potholed surfaces, various high surfaces, and cobblestone surfaces. Furthermore, we found barriers in-between buildings that have a negative impact on the organization of running for disabled runners, such as curbs, cars, cyclists, inappropriate placement of street elements, signs, lighting, trees and green areas, benches, and bins. However, disabled runners perceive attributes inbetween buildings that positively influence running organization and encourage participation of physically disabled runners, such as flat surfaces and interesting architecture, as well as for visually impaired runners, such as lighting, flat surfaces, sidewalk and street connectivity, and special lines. Urban practitioners should prioritize revitalizing in-between buildings through developing accessibility to remove all the impediments that may encourage and promote more disabled people to participate in street running.

\section{Conflicts of Interest}

The authors declare no conflicts of interest regarding the publication of this paper.

\section{References}

Allender, S., Cowburn, G., \& Foster, C. (2006). Understanding Participation in Sport and Physical Activity among Children and Adults: A Review of Qualitative Studies. Health 
Education Research, 21, 826-835. https://doi.org/10.1093/her/cyl063

Badawy, U. I., Jawabrah, M. Q., \& Jarada, E. A. (2020). Adaptation of Accessibility for People with Disabilities in Private and Public Buildings Using Appropriate Design Checklist. International Journal for Modern Trends in Science and Technology, 6, 125-137. https://doi.org/10.46501/IJMTST060627

Bashiti, A., \& Rahim, A. A. (2016). Physical Barriers Faced by People with Disabilities (PwDs) in Shopping Malls. Procedia-Social and Behavioral Sciences, 222, 414-422. https://doi.org/10.1016/j.sbspro.2016.05.199

Belir, O., \& Onder, D. E. (2013, October). Accessibility in Public Spaces: Spatial Legibility for Visually Impaired People. Proceedings of the 9th International Space Syntax Symposium, Seoul, 31 October-3 November 2013, 11.

Beuving, E., \& Michaut, J. P. (2005). Pavement Surface Materials Used in Urban Areas. International Seminar on Urban Pavements, Cracow, 21-22 September 2005, 4.

Bodin, M., \& Hartig, T. (2003). Does the Outdoor Environment Matter for Psychological Restoration Gained through Running? Psychology of Sport and Exercise, 4, 141-153.

https://doi.org/10.1016/S1469-0292(01)00038-3

Borgers, J., Vanreusel, B., Vos, S., Forsberg, P., \& Scheerder, J. (2016). Do Light Sport Facilities Foster Sports Participation? A Case Study on the Use of Bark Running Tracks. International Journal of Sport Policy and Politics, 8, 287-304. https://doi.org/10.1080/19406940.2015.1116458

Breuer, C., Hallmann, K., \& Wicker, P. (2011). Determinants of Sport Participation in Different Sports. Managing Leisure, 16, 269-286.

https://doi.org/10.1080/13606719.2011.613625

Bromley, R. D., Matthews, D. L., \& Thomas, C. J. (2007). City Centre Accessibility for Wheelchair Users: The Consumer Perspective and the Planning Implications. Cities, 24, 229-241. https://doi.org/10.1016/j.cities.2007.01.009

Bundon, A., \& Hurd Clarke, L. (2015). Honey or Vinegar? Athletes with Disabilities Discuss Strategies for Advocacy within the Paralympic Movement. Journal of Sport and Social Issues, 39, 351-370. https://doi.org/10.1177\%2F0193723514557823

Burfoot, A. (2007). The History of the Marathon. Sports Medicine, 37, 284-287. https://doi.org/10.2165/00007256-200737040-00003

Carmona, M. (2010). Contemporary Public Space: Critique and Classification, Part One: Critique. Journal of Urban Design, 15, 123-148. https://doi.org/10.1080/13574800903435651

Collinson, J. A. (2008). Running the Routes Together: Corunning and Knowledge in Action. Journal of contemporary Ethnography, 37, 38-61. https://doi.org/10.1177\%2F0891241607303724

Cooper, R. A. (1990). Wheelchair Racing Sports Science: A Review. Journal of Rehabilitation Research and Development, 27, 295-312.

Deelen, I., Jansen, M., Dogterom, N. J., Kamphuis, C. B., \& Ettema, D. (2017). Do Objective Neighbourhood Characteristics Relate to Residents' Preferences for Certain Sports Locations? A Cross-Sectional Study Using a Discrete Choice Modelling Approach. BMC Public Health, 17, Article No. 943. https://doi.org/10.1186/s12889-017-4949-5

Deelen, I., Janssen, M., Vos, S., Kamphuis, C. B., \& Ettema, D. (2019). Attractive Running Environments for All? A Cross-Sectional Study on Physical Environmental Characteristics and Runners' Motives and Attitudes, in Relation to the Experience of the Running Environment. BMC Public Health, 19, Article No. 366.

https://doi.org/10.1186/s12889-019-6676-6 
Department of the Environment, Transport and the Regions (DETR) (1998). Guidance on the Use of Tactile Paving Surfaces. Department of the Environment, Transport and the Regions.

DePauw, K. P., \& Gavron, S. J. (2005). Disability and Sport. Human Kinetics. https://doi.org/10.5040/9781492596226

DESA, U. (2019). World Urbanization Prospects 2018: Highlights (ST/ESA/SER. A/421).

Diaz, R., Miller, E. K., Kraus, E., \& Fredericson, M. (2019). Impact of Adaptive Sports Participation on Quality of Life. Sports Medicine and Arthroscopy Review, 27, 73-82. https://doi.org/10.1097/JSA.0000000000000242

Edwards, P., \& Tsouros, A. D. (2008). A Healthy City Is an Active City: A Physical Activity Planning Guide. World Health Organization, Regional Office for Europe.

Ettema, D. (2016). Runnable Cities: How Does the Running Environment Influence Perceived Attractiveness, Restorativeness, and Running Frequency? Environment and Behavior, 48, 1127-1147. https://doi.org/10.1177/0013916515596364

Fields in Trust-London (National Playing Fields Association) (2008). Planning and Design for Outdoor Sport and Play. Fields in Trust-London.

Francis, L. (2018). Understanding Disability Civil Rights Non-Categorically: The Minority Body and the Americans with Disabilities Act. Philosophical Studies, 175, 1135-1149. https://doi.org/10.1007/s11098-018-1067-x

Gadais, T., Boulanger, M., Trudeau, F., \& Rivard, M. C. (2018). Environments Favorable to Healthy Lifestyles: A Systematic Review of Initiatives in Canada. Journal of Sport and Health Science, 7, 7-18. https://doi.org/10.1016/j.jshs.2017.09.005

Gehl, J. (2010). Life between Buildings. Van Nostrand Reinhold.

Giles-Corti, B., Gunn, L., Hooper, P., Boulange, C., Diomedi, B. Z., Pettit, C., \& Foster, S. (2019). Built Environment and Physical Activity. In M. Nieuwenhuijsen, \& H. Khreis (Eds.), Integrating Human Health into Urban and Transport Planning (pp. 347-381). Springer. https://doi.org/10.1007/978-3-319-74983-9 18

Gleeson, B. (2001). Disability and the Open City. Urban Studies, 38, 251-265. https://doi.org/10.1080\%2F00420980123531

Hargie, O., Somerville, I., \& Mitchell, D. (2015). Social Exclusion and Sport in Northern Ireland. Social Exclusion and Sport in Northern Ireland.

Hockey, J., \& Allen-Collinson, J. (2006). Seeing the Way: Visual Sociology and the Distance Runner's Perspective. Visual Studies: Journal of the International Visual Sociology Association, 21, 70-81. https://doi.org/10.1080/14725860600613253

Hoekman, R., Breedveld, K., \& Kraaykamp, G. (2017). Sport Participation and the Social and Physical Environment: Explaining Differences between Urban and Rural Areas in the Netherlands. Leisure Studies, 36, 357-370. https://doi.org/10.1080/02614367.2016.1182201

Howie, E. K., Barnes, T. L., McDermott, S., Mann, J. R., Clarkson, J., \& Meriwether, R. A. (2012). Availability of Physical Activity Resources in the Environment for Adults with Intellectual Disabilities. Disability and Health Journal, 5, 41-48. https://doi.org/10.1016/j.dhjo.2011.09.004

Huang, B. X., Chiou, S. C., \& Li, W. Y. (2020). Accessibility and Street Network Characteristics of Urban Public Facility Spaces: Equity Research on Parks in Fuzhou City Based on GIS and Space Syntax Model. Sustainability, 12, Article No. 3618.

https://doi.org/10.3390/su12093618

Hums, M. A., Schmidt, S. H., Novak, A., \& Wolff, E. A. (2016). Universal Design: Moving 
the Americans with Disabilities Act from Access to Inclusion. Journal of Legal Aspects of Sport, 26, 36-51. https://doi.org/10.1123/jlas.2015-0011

Hussein, N. (2018). The Pedestrianisation and Its Relation with Enhancing Walk Ability in Urban Spaces. Journal of Contemporary Urban Affairs, 2, 102-112. https://doi.org/10.25034/ijcua.2018.3666

Ismael, K. S., Mohammed, N. H., \& Rasul, H. Q. (2019). Potentialities in Creating the Pedestrian Malls in the Historical City Centers: A Study Case of Mawlawi Street, Sulaimani, Iraqi Kurdistan. Kurdistan Journal of Applied Research, 4, 31-40. https://doi.org/10.24017/science.2019.1.6

Jared, S. (2018, March). Is Running on Pavement Safe? Master Trainer Jared Stokes Weighs in on This Debate; Giving the Running Fitness Facts and How to Avoid Injury. https://tgnreview.com/2018/03/05/is-running-on-pavement-safe/

Kamphuis, C. B. M., Van Lenthe, F. J., Giskes, K., Huisman, M., Brug, J., \& Mackenbach, J. P. (2008). Socioeconomic Status, Environmental and Individual Factors, and Sports Participation. Medicine \& Science in Sports \& Exercise, 40, 71-81. https://doi.org/10.1249/mss.0b013e318158e467

Kerins, A. (2005). Promoting the Participation of People with Disabilities in Physical Activity and Sport in Ireland. National Disability Authority (NDA). http://nda.ie/publications/health/health-publications/promoting-the-participation-of-p eople-with-disabilities-in-physical-activity-and-sport-in-ireland.html

Kesik, O. A., Demirci, A., \& Karaburun, A. (2012). Analysis of Pavements for Disabled Pedestrians in Metropolitan Cities. Lap Lambert Academic Publishing.

Kirchner, C. E., Gerber, E. G., \& Smith, B. C. (2008). Designed to Deter: Community Barriers to Physical Activity for People with Visual or Motor Impairments. American Journal of Preventive Medicine, 34, 349-352.

https://doi.org/10.1016/j.amepre.2008.01.005

Kiuppis, F. (2018). Inclusion in Sport: Disability and Participation. Sport in Society, 21, 4-21. https://doi.org/10.1080/17430437.2016.1225882

Kostrzewska, M. (2017, October). Activating Public Space: How to Promote Physical Activity in Urban Environment. IOP Conference Series: Materials Science and Engineering, 245, Article ID: 052074. https://doi.org/10.1088/1757-899X/245/5/052074

Lamprecht, M., \& Stamm, H. P. (2006). Bewegung, Sport, Gesundheit. Fakten und Trends aus den SchweizerischenGesundheitsbefragungen 1992, 1997 und 2002. Statsanté. Resultatezu den Gesundheitsstatistiken in der Schweiz. Neuchâtel: Swiss Federal Statistical Office.

Mahmoudi, A., \& Mazloomi, M. (2014). Urban Spaces, Disabled, and the Aim of a City for All: A Case Study of Tehran. International Journal of Sciences: Basic and Applied Research, 14, 530-537.

Martin, J. J. (2002). Training and Performance Self-Efficacy, Affect, and Performance in Wheelchair Road Racers. The Sport Psychologist, 16, 384-395.

https://doi.org/10.1123/tsp.16.4.384

Martin, J. J. (2013). Benefits and Barriers to Physical Activity for Individuals with Disabilities: A Social-Relational Model of Disability Perspective. Disability and Rehabilitation, 35, 2030-2037. https://doi.org/10.3109/09638288.2013.802377

Matthews, B., Hibberd, D., \& Speakman, K. (2015). The Impact of Street Accessibility on Travel and Independence for Disabled People. 14th International Conference on Mobility and Transport for Elderly and Disabled Persons, Lisbon, 28-31 Jul 2015. (Unpublished) 
Meyers, A. R., Anderson, J. J., Miller, D. R., Shipp, K., \& Hoenig, H. (2002). Barriers, Facilitators, and Access for Wheelchair Users: Sbstantive and Methodologic Lessons from a Pilot Study of Environmental Effects. Social Science \& Medicine, 55, 1435-1446. https://doi.org/10.1016/S0277-9536(01)00269-6

Mohammed, N. H. (2016). Livable Streets as an Essential Quality of Social Life: The Case of 15 A ğustos Boulevard (Larnaca Road) of Famagusta, North Cyprus. Master's Thesis, Eastern Mediterranean University (EMU)-Doğu Akdeniz Üniversitesi (DAÜ).

Peters, B. (2001). Transport for the People with Disabilities: Barrier-Free. IATSS Research, 25, 51-60. https://doi.org/10.1016/S0386-1112(14)60006-6

Priyono, B., Rohidi, T. R., \& Soesilowati, E. (2017). Patterns of Public Spaces Based on 'Sport for All' and People's Adaptation Process in Semarang City. The Journal of Educational Development, 5, 59-71.

Richardson, E., Smith, B., \& Papathomas, A. (2017). Disability and the Gym: Experiences, Barriers and Facilitators of Gym Use for Individuals with Physical Disabilities. Disability and Rehabilitation, 39, 1950-1957. https://doi.org/10.1080/09638288.2016.1213893

Rimmer, J. H. (2006). Building Inclusive Physical Activity Communities for People with Vision Loss. Journal of Visual Impairment \& Blindness, 100, 863-865. https://doi.org/10.1177\%2F0145482X0610001S10

Rimmer, J. H., Riley, B., Wang, E., \& Rauworth, A. (2005). Accessibility of Health Clubs for People with Mobility Disabilities and Visual Impairments. American Journal of Public Health, 95, 2022-2028. https://doi.org/10.2105/AJPH.2004.051870

Robert, S. (2020). Public Square: A CNU Journal Congress for the New Urbanism. https://www.cnu.org/

Salha, R., Jawabrah, M., Badawy, U., Jarada, A., \& Alastal, A. (2020). Towards Smart, Sustainable, Accessible and Inclusive City for Persons with Disability by Taking into Account Checklists Tools. Journal of Geographic Information System, 12, 348-371. https://doi.org/10.4236/jgis.2020.124022

Scelza, W. M., Kalpakjian, C. Z., Zemper, E. D., \& Tate, D. G. (2005). Perceived Barriers to Exercise in People with Spinal Cord Injury. American Journal of Physical Medicine \& Rehabilitation, 84, 576-583. https://doi.org/10.1097/01.phm.0000171172.96290.67

Scheerder, J., Breedveld, K., \& Borgers, J. (Eds.). (2015). Running across Europe: The Rise and Size of One of the Largest Sport Markets. Palgrave Macmillan. https://doi.org/10.1057/9781137446374

Shahraki, A. A. (2021). Urban Planning for Physically Disabled People's Needs with Case Studies. Spatial Information Research, 29, 173-184. https://doi.org/10.1007/s41324-020-00343-9

Shields, N., Synnot, A. J., \& Barr, M. (2012). Perceived Barriers and Facilitators to Physical Activity for Children with Disability: A Systematic Review. British Journal of Sports Medicine, 46, 989-997. https://doi.org/10.1136/bjsports-2011-090236

Sholihah, A. B. (2001). Mobility for All: Towards Barrier-Free Environment in Yogyakarta-Indonesia. IATSS Research, 25, 23-31. https://doi.org/10.1016/S0386-1112(14)60003-0

Smith, A. (2015). Events in the City: Using Public Spaces as Event Venues. Routledge. https://doi.org/10.4324/9781315765129

Smith, B., \& Sparkes, A. C. (2019). Disability, Sport and Physical Activity. In N. Watson, \& S. Vehmas (Eds.), Routledge Handbook of Disability Studies (pp. 391-403). Routledge. https://doi.org/10.4324/9780429430817-28 
Smith, B., Kirby, N., Skinner, B., Wightman, L., Lucas, R., \& Foster, C. (2018). Physical Activity for General Health Benefits in Disabled Adults: Summary of a Rapid Evidence Review for the UK Chief Medical Officers' Update of the Physical Activity Guidelines. Public Health England.

Sport England (2010). Accessible Sports Facilities Formerly Known as Access for Disabled People Updated 2010 Guidance. Sport England.

Stevens, C. S. (2007). Living with Disability in Urban Japan. Japanese Studies, 27, 263-278. https://doi.org/10.1080/10371390701685047

Swain, J., French, S., Barnes, C., \& Thomas, C. (Eds.). (2013). Disabling Barriers-Enabling Environments. Sage.

Szaszák, G., \& Kecskés, T. (2020). Universal Open Space Design to Inform Digital Technologies for a Disability-Inclusive Place-Making on the Example of Hungary. Smart Cities, 3, 1293-1333. https://doi.org/10.3390/smartcities3040063

Tiessen-Raaphorst, A. (2016). Running across Europe: The Rise and Size of the Largest Sport Markets. European Journal for Sport and Society, 13, 250-251. https://doi.org/10.1080/16138171.2016.1226032

Titze, S., Stronegger, W., \& Owen, N. (2005). Prospective Study of Individual, Social, and Environmental Predictors of Physical Activity: Women's Leisure Running. Psychology of Sport and Exercise, 6, 363-376. https://doi.org/10.1016/j.psychsport.2004.06.001

Toole, J., Pietrucha, M. T., \& Davis, J. (1999). FHWA Course on Bicycle and Pedestrian Transportation-Instructor's Guide (No. FHWA-RD-99-198). Federal Highway Administration, Office of Safety Research and Development.

Ujma-Wąsowicz, K. (2011). Disabled Youth in Sport Rivalry. What Are the Trends Virtual or Real Competition? Universal Access in Human-Computer Interaction. 6th International Conference on Universal Access in Human-Computer Interaction, Orlando, July 9-14 2011, 390-399. https://doi.org/10.1007/978-3-642-21663-3 42

Ujma-Wąsowicz, K. (2012). Kształtowanie przestrzeni sportowo-rekreacyjnych w mieście. Ewolucja problem. Politechnika Śląska

Ujma-Wąsowicz, K., \& Musioł, T. (2008). Outdoor Sport in the City of the Future: Planning and Designing Issues. WIT Transactions on Ecology and the Environment, 117, $13-$ 22. https://doi.org/10.2495/SC080021

Ujma-Wąsowicz, K., Benek, I., \& Kempka, A. (2021). Badania dostępności architektoniczno-urbanistycznej w Polsce. Studium przypadku. Builder Science, 285, 56-58. https://doi.org/10.5604/01.3001.0014.7952

United Nations (2006). Convention on the Rights of Persons with Disabilities (CRPD). United Nations.

Vaandrager, L. (2007). Running People, Healthy People. In H. Moerbeek, A. Niehof, \& J. van Ophem (Eds.), Changing Families and Their Lifestyles (pp. 315-325). Wageningen Academic Publishers.

Wadey, R., \& Day, M. (2018). A Longitudinal Examination of Leisure Time Physical Activity Following Amputation in England. Psychology of Sport and Exercise, 37, 251-261. https://doi.org/10.1016/j.psychsport.2017.11.005

Women and Equalities Committee (2018). Building for Equality: Disability and the Built Environment. Women and Equalities Committee.

World Health Organization (2011a). Promoting Sport and Enhancing Health in European Union Countries: A Policy Content analysis to Support Action. World Health Organization. 
World Health Organization (2011b). World Report on Disability 2011. World Health Organization.

Xiang, H., Zhu, M., Sinclair, S. A., Stallones, L., Wilkins III, J. R., \& Smith, G. A. (2006). Risk of Vehicle-Pedestrian and Vehicle-Bicyclist Collisions among Children with Disabilities. Accident Analysis \& Prevention, 38, 1064-1070. https://doi.org/10.1016/j.aap.2006.04.010

Yiing, C. F., Yaacob, N. M., \& Hussein, H. (2013). Achieving Sustainable Development: Accessibility of Green Buildings in Malaysia. Procedia-Social and Behavioral Sciences, 101, 120-129. https://doi.org/10.1016/j.sbspro.2013.07.185 